\title{
współczesna powieść historyczna i kultura popularna (prolegomena)
}

„Kontredans, flirt czy galwanizowanie trupa? - oto trzy, do wyboru albo wszystkie razem, możliwości, jakie zawsze stają przed artystą zamierzającym tworzyć dzieło historyczne" ${ }^{\prime 1}$ - pisał w nieco prowokacyjnym tonie Jerzy Weinberg, otwierając rozważania nad sztuką pisarską Aleksandra A. F. Bronikowskiego. Czy istotnie? Czy też może wyznaczone przez Weinberga $\mathrm{z}$ udziałem metafory punkty odniesienia dla pisarskich strategii opowiadania o przeszłości pozostają w równej mierze - co sam fenomen powieści historycznej - zmistyfikowane, aby możliwa stała się funkcjonalizacja i instrumentalizacja sięgania po historyczne tworzywo?

Niewątpliwie rację ma Kazimierz Bartoszyński, piszący o wieloaspektowym zakorzenieniu powieści historycznej w sferze znaków kultury². To przecież przez nie czytelnik postrzega artystyczne realia świata przedstawionego, co niewątpliwie umożliwiają mu skonwencjonalizowane obrazy epoki, funkcjonujące $\mathrm{w}$ imaginarium communis. Stereotypy poznawcze, do których odwołuje się zarówno piszący, jak i czytelnik, stanowią w tym wypadku płaszczyznę komunikacyjną. Dzięki niej zaś możliwy jest nie tylko dialog międzypokoleniowy, ale też uwzględnienie dystansu czasowego między pierwodrukiem a lekturą utworu (uwikłanie czasowe dzieła literackiego jest o tyle istotne, że pozostaje w korelacji ze zmiennym historycznie kontekstem społeczno-obyczajowym). Wspólnota lekturowa pozwala bowiem uzgodnić topikę utożsamianą - w duchu Arystotelesa - ze

${ }^{*}$ Uniwersytet Łódzki, Wydział Filologiczny, Zakład Dydaktyki Języka i Literatury Polskiej, e-mail: adammazurkiewicz@o2.pl.

${ }^{1} \mathrm{~J}$. Weinberg, Aleksander Bronikowski a historia - na przykładzie jednej powieści, "Annales Universitatis Mariae Curie-Skłodowska. Sectio FF" 2002-2003, t. XX-XXI, s. 289.

${ }^{2}$ Zob. K. Bartoszyński, Konwencje gatunkowe powieści historycznej, "Pamiętnik Literacki” 1984 , z. 2, s. 5. 
stereotypem myślowym³ ${ }^{3}$ Ten zaś z kolei umożliwia wykorzystanie funkcjonujących w społeczeństwie clichés, dzięki którym odbiorca może odnaleźć pozaartystyczny punkt odniesienia dla wizji rzeczywistości prezentowanej w utworze literackim.

Obieg popularny, który we współczesnej kulturze - w związku z przemianami społeczno-obyczajowymi - przejął rolę zarezerwowaną dla rejestru wysokiego, sięga po stereotyp myślowy w szczególny sposób. Jest on w tekstach popkulturowych dość często traktowany nie tyle jako punkt wyjścia, umożliwiający reinterpretację owego stereotypu (to bowiem należy przede wszystkim do domeny sztuki awangardowej), lecz raczej punkt dojścia. Stereotyp w tym ujęciu pozostaje swoistym tworzywem; jemu też podporządkowana zostaje aksjologia świata przedstawionego. Naszkicowana tu właściwość rejestru niższego kultury związana jest zresztą z immanentną specyfiką literatury popularnej, w której powtarzalność schematów generujących fabułę prowadzi do waloryzowania rozwiązań utrwalonych w imaginarium communis ${ }^{4}$. Toteż niewątpliwie rację ma Ewelina Stanios-Korycka, deklarująca:

Forma literatury popularnej jest swego rodzaju filtrem, który przedstawia treści stanowiące rezerwuar pamięci kulturowej w sposób petryfikujący wyobrażenia i przekonania czytelnika. Jeśli zaś przekazuje nieznane dotąd pojęcia, to czyni to w sposób przystępny, umożliwiający włączenie czytelnika w nowy krąg zbiorowych wyobrażeń ${ }^{5}$.

Dominacja w popkulturze konwencji nad innowacją jest kwestią istotną nie tylko dla interpretacji dzieła literackiego (resp. tekstu kultury), bowiem sposób, w jaki ukazywane zostają etyczne sensy wyborów fikcyjnych bohaterów, wpływa na postrzeganie realnego świata pozatekstowego. Tym bardziej, że - przywołując rozróżnienie wartości estetycznych, dokonane przez Mieczysława Wallisa - twórcy obiegu popularnego chętnie posługują

${ }^{3}$ Zob. J. Abramowska, Topos i niektóre miejsca wspólne badań literackich, „Pamiętnik Literacki" 1982, z. 1-2, s. 9. Znacząca pod tym względem wydaje się definicja Abramowskiej: "[topos] jest rezultatem petryfikacji tradycyjnego motywu, który zostaje trwale powiązany z pewnym znaczeniem, zastosowaniem oraz z rozpoznawalną, "półgotową formą językową" (tamże, s. 11-12).

Co istotne, sam Arystoteles, niejako wbrew tytułowi Topik, nie definiuje tego pojęcia. Zadowala się jedynie ogólnikową deklaracją: „Celem niniejszego traktatu jest odkrycie metody, za pomocą której można by wnioskować z ogólnie przyjętych sądów o każdym przedłożonym problemie, przy czym sami, wypowiadając się, nie powiedzielibyśmy niczego sprzecznego z naszym twierdzeniem" (tenże, Topiki. O dowodach sofistycznych, przeł. K. Leśniak, Warszawa 1978, s. 3).

${ }^{4}$ Zob. A. Martuszewska, Czym "ta trzecia" kusi badacza literatury?, [w:] taż, "Ta trzecia". Problemy literatury popularnej, Gdańsk 1997, s. 14-15; A. Sikora, Dzieje Polski w obrazach fabularnych Józefa Ignacego Kraszewskiego jako przykład beletrystyki popularnej, [w:] Powieść historyczna dawniej i dziś, red. R. Stachura, T. Budrewicz, B. Faron, K. Gajda, Kraków 2007, s. 128.

${ }^{5}$ E. Stanios-Korycka, Między pamięcia kulturowa a kultura popularna. Wybrane aspekty relacji na przykładzie sposobów kreowania Bizancjum w historiach alternatywnych, "Acta Humana” 2014, nr 1, s. 53. 
się wartościami „ostrymi” (patosem, wzniosłością, brzydotą) ${ }^{6}$. Te bowiem pozwalają na bardziej wyjaskrawione ukazanie wartości etycznych i uczuć-afektów oraz ułatwiają skuteczniejsze wykorzystanie strategii perswazji Umożliwiają również jednoznaczny podział bohaterów na pozytywnych i negatywnych, a jednocześnie grę aksjologią świata przedstawionego tak, iż mamy do czynienia $w$ jego ramach z relatywizacją zła, bardziej fabularnie atrakcyjnego niż pozytywne wzorce zachowań. Ponieważ zaś zachwiana została równowaga społecznego funkcjonowania obiegów kulturowych (sama ich koncepcja jest zresztą w coraz mniejszym stopniu adekwatna do obserwowanych współcześnie przemian), dzisiejsze myślenie naznaczone zostało dominującym w popkulturze stylem podporządkowanym „ostrym wartościom" estetycznym. Co istotne, owa właściwość obiegu popularnego wpływa nie tylko na postrzeganie współczesności, lecz w dużym stopniu określa też obraz historycznej przeszłości, przyczyniając się do trwania resentymentów historycznych $i$ "walki na słowa" w sferze polityki pamięci ${ }^{8}$.

Istotna rola przypada $\mathrm{w}$ owych starciach ideologicznych popularnej powieści historycznej. Wespół z innymi mediami popkultury pozostaje ona „medium cyrkulacyjnym” (określenie Astrid Erll), tj. umacniającym wzorce dzięki konsolidacji mitów społecznych właściwych danej kulturze$^{9}$. Współtworzy też formy reprezentacji, legitymizujące funkcjonujące społecznie obrazy postpamięci, tj. pamięci zakorzenionej nie w wydarzeniach, dostępnych świadkom bezpośrednio, lecz utrwalonych $\mathrm{w}$ „pamięci kulturowej" (określenie Jana Assmanna) ${ }^{10}$. Nieprzypadkowo przecież Ka-

${ }^{6}$ Zob. M. Wallis, Wartości estetyczne łagodne i ostre, [w:] tenże, Przeżycie i wartość. Pisma z estetyki i nauki o sztuce 1931-1949, Kraków 1968, s. 189-190.

${ }^{7}$ Perswazyjny wymiar tekstów kultury popularnej ma związek z jej konserwatywnym charakterem. O ile bowiem obieg wysoki to domena eksperymentów myślowych i artystycznych, zmierzających do podważenia zastanej wizji reprezentowania rzeczywistości pozatekstowej, popkultura ma do spełnienia odmienną funkcję - utwierdza swych odbiorców $\mathrm{w}$ dotychczasowych wyborach, promując wartości zachowawcze.

${ }^{8}$ Potrzebę dookreślonej polityki historycznej, będącej efektem przemyślanych działań, wyraża Zbigniew Gluza: „Potrzebujemy takiej polityki historycznej, co do której uzyskać można szeroki konsensus społeczny. Nie skierowanej przeciw nikomu, nie używającej historii jako oręża w walce o władzę, a przeciwnie - służącej prawdzie, a zarazem spełniającej funkcje społeczne" (tenże, Powinności polityki historycznej, [online] http://historiaimedia.org/wp-content/uploads/2008/09/powinnosci_polityki_historycznej.pdf (dostęp: 10.09.2016). Niemały wpływ na relację między polityką pamięci a powieścią historyczną ma geneza tej formy beletrystyki. Bogusław Zieliński, poszukując związków strukturalnych pomiędzy polską i serbską powieścią historyczną, upatrywał ich w sfunkcjonalizowaniu owego nurtu powieści jako patriotycznej wykładni tradycji, medium narodowej świadomości oraz pełnieniu przez niego kompensacyjnej roli mitu wielkości narodowej (zob. tenże, Serbska powieść historyczna, Poznań 1998, s. 16).

${ }^{9}$ Zob. A. Erll, Literatura jako medium pamięci zbiorowej, przeł. M. Saryusz-Wolska, [w:] Pamieć zbiorowa i kulturowa. Wspótczesna perspektywa niemiecka, red. M. Saryusz-Wolska, Kraków 2009, s. 233.

${ }^{10}$ Zob. J. Assmann, Pamięć kulturowa. Pismo, zapamiętywanie i polityczna tożsamość w cywilizacjach starożytnych, przeł. A. Kryczyńska-Pham, Warszawa 2008, s. 15. Badacz definiuje zjawisko „pamięci kulturowej” jako świadomy stosunek społeczności do minionych czasów; jest ona osadzona w przestrzeni kulturowej i przekazywana przez różne media komunikacji społecznej. Co istotne, jej "generatorem" pozostają instytucje tworzące system konstruujący tożsamość grupową - stąd niezwykle istotną rolę w jej kształtowaniu pełni wspominana już spójna polityka pamięci (Zob. tamże). 
tarzyna Kaniowska podkreśla relację pomiędzy pamięcią (również historyczną) i tożsamością: „Pamięć, kumulując dawne doświadczenie, staje się też wiedzą o nim, a zatem doświadczenie i wiedza konstytuują naszą tożsamość. Brak pamięci oznacza utratę tożsamości. Nie pamiętając bylibyśmy nikim"11. Wyrażone w przytoczonych tu słowach przekonanie - odwołajmy się do XIX-wiecznego rozdziału tych pojęć, który legł u podstaw klasycznej historiografii - o dominacji pamięci nad historią uzmysławia, w jaki sposób jest legitymizowany osobisty stosunek do przeszłości - nawet za cenę możliwego zniekształcenia jej obrazu na skutek subiektywizmu spojrzenia (przeciwnie historia; to, że jej domeną pozostawał obiektywny zapis dziejów miało gwarantować wiarygodność przekazu ${ }^{12}$ ).

Jednakże polityka pamięci nie istnieje w oderwaniu od sytuacji komunikacyjnej, w której funkcjonuje pisarz i jego czytelnik. Odbiorca zaś, co podkreśla Anna Legeżyńska, po roku 1989 w coraz większym stopniu kształtowany jest przez twórczość popularną, stanowiącą mieszankę światopoglądów i estetyk. Niemały wpływ na te przewartościowania miały bardzo liczne przekłady z literatury obcej (głównie anglojęzycznej), pod których wpływem formował się gust czytelniczy. Publikowane wówczas powieści popularne ukazywały ,'swiat podrobiony"13. Złożony został on z wielu niekoherentnych elementów: „[utwory te] ukazywały [...] świat formowany z miksowanej tradycji literackiej, łącząc wątki kultury celtyckiej, średniowiecznej,

Sam termin postpamięć - który zawdzięczamy Marianne Hirsch (Zob. taż, The Generation of Postmemory, „Poetic Today” 2008, nr 1, s. 103-128) - jest nacechowany semantycznie; pierwotnie badaczka odnosiła go do sytuacji „drugiego pokolenia Holocaustu”. Na zagrożenia wynikające z nadużycia tego pojęcia wskazuje Małgorzata Pakier; zob. taż, Pogranicza pamięci i postpamięci. O Zagładzie $i$ kulturze masowej raz jeszcze, [w:] Peryferie i pogranicza: o potrzebie różnorodności, red. B. Jałowiecki, S. Kapralski, Warszawa, 2011, s. 265-282 (tu zwłaszcza o płynności granic między tym, co zapamiętane i wyobrażeniem przeszłości, s. 276). O tym, do jakiego stopnia teksty kultury popularnej są uwikłane w ideologiczne dyskursy, świadczy lektura pracy Marcina Napiórkowskiego Powstanie umartych. Historia pamięci 1944-2014 (2016). Badacz, na przykładzie kulturowej recepcji doniosłego dla dziejów Polski wydarzenia, jakim było powstanie warszawskie, obserwuje sposób funkcjonowania tego wydarzenia w dyskursie społecznym oraz jak zostaje zawłaszczane przez ideologicznych adwersarzy oraz rynek (zob. tamże, s. 353-397). Jednocześnie niemożliwa wydaje się rezygnacja z szans oferowanych przez postpamięć. Ta bowiem, co podkreśla Anna Mach, umożliwia poszukiwanie sposobów komunikacji w sytuacji, gdy poprzednie możliwości zdezaktualizowały się (zob. taż, Świadkowie świadectw. Postpamięć Zagłady w polskiej literaturze najnowszej, Warszawa-Toruń 2016, s. 87).

${ }^{11} \mathrm{~K}$. Kaniowska, "Memoria" $i$ "postpamięć" a antropologiczne badanie wspólnoty, „, Łódzkie Studia Etnograficzne" 2004, t. 43: Codzienne i niecodzienne. O wspólnotowości w realiach dzisiejszej Łodzi, s. 15. Przywoływany tu przez Kaniowską problem społecznego statusu pamięci komplikuje się współcześnie w ramach paradygmatu postmodernistycznego. Jej funkcja legitymizująca została - w myśl supozycji Pauliny Małochleb - wyparta przez inne: pamięć-archiwum, pamięć-dystans oraz pamięć-obowiązek (zob. taż, Przepisywanie historii. Powstanie styczniowe w powieści polskiej w perspektywie pamięci kulturowej, Warszawa-Toruń 2014, s. 10).

${ }^{12}$ Zob. K. L. Klein, O pojawieniu się pamięci w dyskursie historycznym, przeł. M. Bańkowski, „Konteksty” 2003, nr 3-4, s. 42-56. Nie należy przy tym zapominać, iż obiektywizacja przekazu historycznego nie wyklucza jego funkcjonowania w dyskursie władzy, dominacji i wykluczenia. Nieprzypadkowo autorki książki Powiedzieć prawdę o historii podkreślają istnienie relacji między przekazem wiedzy historycznej, a perspektywą, z jakiej jest to czynione (zob. J. Appleby, L. Hunt, M. Jacob, Powiedzieć prawdę o historii, przeł. S. Amsterdamski, Poznań 2000, s. 287).

${ }^{13}$ Określenie Przemysława Czaplińskiego. Zob. tenże, Świat podrobiony. Krytyka i literatura wobec nowej rzeczywistości, Kraków 2003. 
baśniowej, romantycznej, popularnej"14. Z kolei Jerzy Topolski, wskazując na zwrot narratywistyczny we współczesnej historiografii, podkreśla obecność badacza jako kształtującego wizję przeszłości: „W narracji historycznej wyraża się wizja świata i człowieka prezentowana przez historyka"15.

Analogiczny do zauważanego przez Topolskiego mechanizm - motywowany wskazanym przez Legeżyńską charakterem świata przedstawionego rodzimej prozy po 1989 - można odnaleźć na kartach powieści historycznej; nie jest bowiem obojętna dla interpretacji dziejów (a tym samym ich ukazania w utworze literackim) pozycja ideologiczna, deklarowana bądź przyjmowana implicite przez twórcę. Reprezentatywny pod tym względem pozostaje obraz wieku XVII, jaki można wysnuć z twórczości Bohdana Królikowskiego i Jacka Komudy. Dla obu twórców „arche-tekstem” pozostaje przede wszystkim Trylogia (1884-1888) Henryka Sienkiewicza. Jednakże różnice $w$ indywidualnych realizacjach artystycznych wynikają nie tylko z poetyki immanentnej każdego z pisarzy, ale i światopoglądu stanowiącego zaplecze ideologiczne ich prozy. Do pewnego stopnia można oczywiście upatrywać przyczyn owych różnic w kontekście historycznym czasów, kiedy przywołani tu pisarze ogłaszali swe opowieści (Królikowski w latach 1980-1983; Komuda - po 1989), jednakże takie stanowisko zdaje się nadmiernie upraszczające. Należy przy tym pamiętać, iż twórczość Komudy nie zawęża się jedynie do pododmiany "fantasy historycznej", jaką jest "fantasy/fantastyka szlachecka"16. To również autor realistycznych powieści osadzonych w okresie XVII-wiecznych wojen z Moskwą (cykl Orty na Kremlu, 2009-2013), mniej znanych epizodów walk z okresu powstań kozackich, takich jak bitwa pod Batohem w 1652 (Bohun, 2006), i starć Polski ze Szwecją o ujście Wisły z lat 1626-1629 (Galeony wojny, 2007-2008). Jest on też twórcą popularnonaukowego opracowania Warchoty i pijanice, czyli poczet hultajów z czasów Rzeczypospolitej szlacheckiej (2004); kompendium to

${ }^{14}$ A. Legeżyńska, Literatura polska po 1989 roku wobec uniwersum tradycji, [w:] Transformacja w kulturze i literaturze polskiej 1989-2004, red. B. Bakuła, Poznań 2007, s. 17.

${ }^{15} \mathrm{~J}$. Topolski, Jak się pisze i rozumie historię. Tajemnice narracji historycznych, Warszawa 1996, s. 102. Znaczące pod tym względem pozostają słowa Haydena Whitèa, deklarującego: "Nie ma historii bez historyków. Wszystko, co mamy, to dokumenty [...]. Na ich podstawie możemy zbudować dowolnie wiele opowieści o przeszłości" (Pisać historię z która można żyć. Z Haydenem Whitem rozmawia Stawomir Sierakowski, „Krytyka Polityczna” 2005, nr 7-8, s. 228). Co więcej, można by do przywołanych tu słów dodać konstatację Ewy Domańskiej, akcentującej retoryczny charakter wypowiedzi historycznych: „Narracja historyczna nie jest jedynie przekaźnikiem zawsze mniej czy bardziej hipotetycznych informacji o przeszłości. Jest ona równocześnie określoną strukturą retoryczną nastawioną na przekazanie odbiorcom także przekonań historyka" (taż, Filozoficzne rozdroża historii, [w:] E. Domańska, J. Topolski, W. Wrzosek, Między modernizmem a postmodernizmem. Historiografia wobec zmian w filozofii dziejów, Poznań 1994, s. 37).

${ }^{16}$ Termin ten, intencjonalnie mający walor operacyjnego, $\mathrm{w}$ istocie zdaje się przejawem „nadprodukcji terminologicznej”, właściwej dla „krytyki wewnętrznej” (tj. pisanej „przez fanów dla fanów") i pojawia się głównie w różnych zestawieniach na stronach internetowych; zob. np. http://lubimyczytac.pl/ksiazki/polka/59807/jacek-komuda-i-fantastyka-szlachecka (dostęp: 14.09.2016). Można jednakże zarazem traktować owo pojęcie - z perspektywy socjologii odbioru i komunikacji literackiej - jako przejaw świadomości istnienia odrębnego (posłużmy się językiem matematyki) podzbioru prozy historycznej, wydzielonego na podstawie kryterium tematycznego. 
pozostaje komplementarne wobec utworów beletrystycznych (Veto, 1995; Wilcze gniazdo, 2002; Nobile verbum, 2003) ${ }^{17}$.

Pośród kwestii związanych ze statusem powieści historycznej we współczesnym obiegu popularnym kultury wyłaniają się następujące zagadnienia:

- związek z tradycją gatunkową powieści historycznej w jej różnych odmianach;

- relacja do innych odmian gatunkowych literatury popularnej;

- relacja pisarskich wizji historii z uzgodnionymi społecznie.

Poniżej omówimy je kolejno. Już teraz należy jednak zaznaczyć, iż wyszczególnione tu funkcje pozostają w ścisłym związku z sobą. Jeżeli jednakże zdecydowaliśmy się na ich arbitralny rozdział, uczyniliśmy to, pragnąc zachować klarowność wywodu.

\section{Związek z tradycją gatunkową powieści historycznej w jej różnych odmianach}

Konwencjonalna popularna powieść historyczna - o czym przypominają autorzy Słownika literatury popularnej (1997; wyd. 2, 2006) - szczególnie uwydatnia dystans czasowy pomiędzy światem przedstawionym a pozatekstową rzeczywistością czytelnika; akcentują oni również wpływ modelu wypracowanego w literaturze anglojęzycznej przez Waltera Scotta ${ }^{18}$.

W rodzimych utworach o przeszłości walterskotyzm, jako zespół cech właściwych określonemu nurtowi powieści historycznej, ma długą tradycję, sięgającą romantyzmu przedlistopadowego ${ }^{19}$. „Epoka walterskotyzmu” sensu stricto $\mathrm{w}$ literaturze polskiej ograniczona zostaje datami 1821-1846 (odpowiednio: początek druku Jana z Tęczyna Juliana Ursyna Niemcewicza oraz publikacja Listopada Henryka Rzewuskiego i Zygmuntowskich cza-

${ }_{17}$ Komuda to również współautor - z Marcinem Baryłką i Maciejem Jurewiczem (w pierwszej edycji) oraz Michałem Mochockim i Arturem Machlowskim (w drugim wydaniu) - gry fabularnej Dzikie Pola (1997; wyd. 2, 2005). Jest też konsultantem gry komputerowej Kozacy 3 (2016, GSC Game World). Wespół z przywołanymi tu tekstami kultury jego twórczość popularyzująca wiedzę o Rzeczypospolitej szlacheckiej i beletrystyczna współtworzą spójną wizję przeszłości, ukazując wielkość Polski XVII wieku. Jej podstawą jest tęsknota za „złotą wolnością", będącą zresztą wyrazem skonwencjonalizowanej wizji, której kwintesencją pozostaje Sienkiewiczowski Kmicic. Charakteryzując ogólnie XVII-wieczną szlachtę, Komuda pisał: „Każdy z dawnych panów braci starał się pokazać siebie jako prawdziwego Sarmatę - mężczyznę z krwi i kości, który potrafi stawić czoła nawet największemu niebezpieczeństwu. Pokazać się jako człowiek pełen fantazji i honoru, ceniący wolność i swobodę, lecz także staropolską fantazję. [...] Dla prawdziwych Sarmatów niczym był pojedynek, sejmikowa czy karczemna zwada" (tenże, Wstęp, [w:] tenże, Warchoły i pijanice, czyli poczet hultajów z czasów Rzeczypospolitej szlacheckiej, Lublin 2004, s. 7). Osobną kwestią pozostaje, do jakiego stopnia obraz przeszłości, który można wywieść z opowieści Komudy, nosi znamiona „przeszłości użytecznej" (usable past; termin autorstwa H. S. Commagera) społecznie. Obraz wieloetnicznej Rzeczypospolitej szlacheckiej zostaje w utworach tych bowiem zmistyfikowany, a jednocześnie okazuje się mało znaczący dla współczesności (zob. M. Zaleski, Naprzód w przeszłość, [w:] tenże, Formy pamięci, Gdańsk 2004, s. 179).

${ }^{18}$ Zob. Stownik literatury popularnej, red. T. Żabski, Wrocław 2006 [wyd. 2 popr. i uzup.], hasło: Powieść historyczna, s, 459, 461.

${ }^{19}$ Zob. Słownik literatury polskiej XIX wieku, red. J. Bachórz, A. Kowalczykowa, Wrocław 2009, s. 23-24, hasło: Angielsko-polskie związki literackie. 
sów Józefa Ignacego Kraszewskiego) ${ }^{20}$. Jednakże zarazem "długie trwanie" walterskotyzmu wykracza poza wiek XIX. Jest to już wówczas walterskotyzm zasymilowany przez medium romantyzmu. Charakterystyczne dla tego nurtu wyznaczniki odnajdujemy jednakże nie tylko w ówczesnym, ale i współczesnym nurcie popularnej powieści historycznej. Zarówno bowiem w XIX wieku, jak i dziś dominantą poetyki tych utworów pozostaje „mały realizm" szczegółów historycznych. Stanowią one jedynie tło dla heroicznych czynów postaci mniej lub w ogóle nieznanych dziejopisarzom okresu, w którym osadzona zostaje akcja utworu ${ }^{21}$. Jeśli zaś, jak w wypadku Hubala Komudy, protagonistą jest tytułowy legendarny dowódca, to tym, z którego perspektywy referowane są jego losy, pozostaje nieznany bliżej żołnierz.

Utwór ten stanowi interesujący przykład realizacji wzorca powieści walterskotowskiej. Mamy w niej do czynienia z syntopią tego nurtu powieści historycznej z jego aktualizacją $\mathrm{w}$ duchu prozy Sienkiewicza ${ }^{22}$. Zarówno bowiem $\mathrm{w}$ Trylogii, jak i Hubalu pojawia się przeniesienie czasowe romantycznego rysu protagonistów ${ }^{23}$. Sienkiewicz nadaje ów rys bohaterom XVII-wiecznym; Komuda - postaciom z I połowy XX wieku. Obaj przywołani pisarze zdają się traktować tradycję romantyczną jako element mitologii społecznej. O ile jednak w wypadku autora Trylogii mamy do czynienia z pisaniem „ku pokrzepieniu serc” $\mathrm{w}$ dobie utraty przez Polskę niepodległości, Komuda zastanawia się nad żywotnością i atrakcyjnością romantyzmu dziś, $\mathrm{w}$ dobie kresu tego paradygmatu ${ }^{24}$. Znaczące przy tym jest wykorzystanie w powieści Komudy figury konia jako poromantycznego atrybutu polskości, zakorzenionego w sztuce (między innymi w XIX-wiecznym malarstwie rodzajowym Juliusza i Wojciecha Kossaków oraz Antoniego Brodowskiego). Apoteozą utożsamienia "duszy polskiej” z tym zwierzęciem zdaje się zakończenie utworu: „Minąwszy poszczerbione granie Tatr, popędził ku sanockim pogórzom, pagórom Lubelszczyzny i tam... przebiegłszy całą Polskę, zniknął, rozwiał się jak letnia mgła"25.

${ }^{20}$ Zob. tamże, s. 24.

${ }^{21}$ Zob. J. Jarowiecki, O powieści historycznej Józefa Ignacego Kraszewskiego, Kraków 1991, s. 10-11. Niekiedy w realizacjach epigońskich, np. cyklu - wzorowanych na utworach Marka Krajewskiego - powieści kryminalnych Konrada T. Lewandowskiego (Magnetyzer, 2007; Bogini z Labradoru, 2007; Elektryczne perty, 2008; Perkalowy dybuk, 2009; Śląskie dziękczynienie, 2010; Rumuńskie kawony, 2015) heroizm perypetii głównych bohaterów zostaje "uzupełniony” wątkami erotycznymi. Te jednakże - w konfrontacji z ustaleniami historyków i „przekazami z epoki" (zob. np. K. Janicki, Epoka hipokryzji. Seks i erotyka w przedwojennej Polsce, Kraków 2015) - pozostają "gorszące" jedynie do takiego stopnia, do jakiego zgorszonym pragnie poczuć się sam czytelnik.

${ }^{22}$ Zob. J. Lyszczyna, Romantycy - nasi współcześni?, „Postscriptum” 2002, nr 4, s. 9.

${ }^{23}$ Do pewnego stopnia można wobec powieści Komudy mówić o wpływie romantyzmu krajowego. Pojawia się w nich - w myśl supozycji Małgorzaty Łoboz - apoteoza ojczyzny z bogactwem kolorytu lokalnego oraz (auto)realizacja w doświadczeniu obywatelskim (z uwagi na okoliczności takim obowiązkiem obywatelskim dla protagonisty Hubala stała się walka zbrojna); Zob. taż, My, Europejczycy... Romantyków krajowych przekraczanie bliższych $i$ dalszych granic, [w:] Romantyzm krajowy - profil lokalny i oswajanie Europy, red. M. Łoboz, A. Kuniczuk-Trzcinowska, Wrocław 2016, s. 12.

${ }^{24}$ Zob. M. Janion, Kres paradygmatu, „Rzeczpospolita” 1992, nr 63, s. 8-9.

${ }^{25}$ J. Komuda, Hubal, Lublin 2016, s. 754. Obraz ten koresponduje zresztą nie tylko ze skonwencjonalizowaną sarmacko-romantyczną wizją „Polaka na koniu”, ale i odpowiada jej aktualizacji we współczesnym ruchu narodowo-prawicowym; zob. Z. Jasłowski, Koń a sprawa 


\section{Relacja do innych odmian gatunkowych literatury popularnej}

Ambicją twórców powieści historycznej, funkcjonującej w obiegu popkulturowym, nie jest ani „powiedzieć, jak to naprawdę było" (postulat Leopolda von Rankego, który legł u źródeł tradycyjnej historiografii), ani odtworzyć dzieje z perspektywy ich doświadczenia przez jednostkę, uwikłaną w różnorakiej natury uwarunkowania (tak czynili historycy związani z kręgiem "Annales"); jedynie też pozornie zdają się akceptować propozycję Rolanda Barthesa, by język historiografii utożsamić z literackim ${ }^{26}$. Przeciwnie, dość często można zauważyć tendencję do podwojenia perspektywy czasowej: przeszłość, z której autorzy czerpią inspirację do kreślenia obrazu świata przedstawionego, zostaje ukazana przez współczesną świadomość i wrażliwość estetyczną. Prawidłowość tę celnie opisał Janusz Tazbir, akcentujący relację pomiędzy "horyzontem oczekiwañ" założonego czytelnika a odzwierciedleniem „ducha epoki”, w której powstało dane dzieło literackie: „Im bardziej utwór jest nastawiony na masowego odbiorcę, tym plastyczniej chyba odzwierciedla aktualne, ortodoksyjne i - opozycyjne, nurty epoki"27.

Korzystając $\mathrm{z}$ oferowanej przez beletrystykę swobody twórczej pisarze funkcjonujący w obiegu popularnym nierzadko "wpisują" w konwencję powieści historycznej mechanizmy gatunkowe właściwe innym odmianom powieści popularnej. Atrakcyjne pod tym względem wydają się przede wszystkim te gatunki literatury popularnej (kryminał, romans i różnie motywowana fantastyka - naukowa, grozy, fantasy), oferujące łatwo rozpoznawalne struktury gatunkowe. Tym samym pisarze owi tworzą powieść quasi-historyczną, w której rekwizytornia i realia świata przedstawionego - jakkolwiek inspirowane historią - zostają sfunkcjonalizowane

polska: dwór, pałac i stadnina, „RODAKpress. Magazyn Politycznie Niepoprawny”, [online] http://www.rodaknet.com/rp_jaslowski_8.htm (dostęp: 15.09.2016).

${ }^{26}$ Zob. R. Barthes, Dyskurs historii, przeł. A. Rysiewicz, Z. Kloch, „Pamiętnik Literacki” 1984, z. 3, s. 235-236. Z zaproponowanej przez Barthesa perspektywy zrozumiałe staje się, dlaczego Hayden White w jednej z prac pisze o "poetyce historii” (Poetic of History); zob. tenże, Metahistory: The Historical Imagnation in Nineteenth-Century Europe, Baltimore-London 1975, s. 1. Interesującym komentarzem do stanowisk przywołanych tu badaczy zdają się słowa Lindy Hurtcheon, wskazującej na konsekwencje zniesienia różnicy między dyskursem historycznym i literackim: „Formalne połączenie historii i fikcji [...] poprzez wspólne mianowniki intertekstualności i narracyjności przedstawia się zwykle nie jako redukcję [...] zasięgu i znaczenia fikcji, ale raczej jako ich rozszerzanie się" (taż, Historiograficzna metapowieść: parodia i Intertekstualność historii, przeł. J. Margański, [w:] Postmodernizm. Antologia przekładów, red. R. Nycz, Kraków 1998, s. 390).

${ }^{27}$ J. Tazbir, Powieść historyczna odbiciem wspótczesności, [w:] tenże, Prace wybrane, red. S. Grzybowski, Kraków 2002, t. 5: Szkice o literaturze i sztuce, s. 330. Oczywiście naszkicowana przez Tazbira prawidłowość nie wyklucza możliwych potencjalnie innych rozwiązań. Literackim echem konstatacji Tazbira zdają się słowa jednego z bohaterów Terleckiego: „Nie możemy mieć pewności, że zrozumiemy uczynki tych, którzy żyli przed nami. Znamy jedynie własny sąd o ich postępowaniu, poznać możemy sądy innych [...]. Poznamy fakty. Przyczyny wynajdujemy sami. Te same zjawiska na przestrzeni dziejów ludzie tłumaczą sobie zupełnie odmiennie. Własne sądy uzależnione są od warunków, w jakich przychodzi im się kształtować" (W. Terlecki, Dwie głowy ptaka, [w:] tenże, Dwie głowy ptaka. Powrót z Carskiego Sioła, Warszawa 1975, s. 158-159). 
i pełnią nierzadko rolę jedynie egzotycznego "ozdobnika"28. Niewątpliwie do owego, sygnalizowanego przez badaczkę, kolorytu należy aspekt motywacji psychologicznych postaci, pełniący istotną rolę na przykład w prozie Teodora Parnickiego. Nazwisko tego pisarza zostaje przywołane tu nieprzypadkowo, jest on bowiem twórcą postulującym na kartach jednego ze szkiców krytycznych konieczność odwołania się artysty do sfery imaginacji w uzupełnieniu tego, co zostało pominięte w „relacjach z epoki”: „Pisarz ma prawo wypełnienia wyobraźnią twórczą luk powstałych wskutek braków materiałów źródłowych"29. Uwaga ta może wydawać się banalna, jednakże w konfrontacji z praktyką twórczą taką nie jest. W istocie bowiem Parnicki wskazuje na kwestię rudymentarną dla powieściopisarstwa historycznego: granicę, poza którą historia staje się nie tyle źródłem, co pretekstem opowieści ${ }^{30}$. Mechanizm, jaki twórcy opowieści historyczno-fantastycznych bądź kryminałów historycznych wykorzystują w celu sfunkcjonalizowania przywołań sztafażu historycznego, celnie opisała Ewa Tierling-Śledź na marginesie omówienia powieści Marka Świerczka Bestia (2007):

Nie unieważniając historii i jej sensów, operując schematem powieści grozy, powieściopisarz zwraca uwagę na literackość prowadzonej przez siebie gry z historią utrwaloną często w mitach, stereotypach czy kliszach literackich stanowiących jedyne medium dostępu do niej ${ }^{31}$.

Utwory powstałe z kontaminacji powieści historycznej i różnych gatunków literatury popularnej to "hybrydy genologiczne” (na przykład kryminał historyczny i retro; fantastyka steampunk, fantasy historyczna). Są one - z perspektywy marketingowej - adresowane do szerszego kręgu odbiorców niż jedynie miłośników opowieści o dziejach minionych ${ }^{32}$. Zmieniają

${ }^{28}$ Jedynie niekiedy, w jednostkowych realizacjach artystycznych (np. powieściach Krajewskiego i wybranych utworach Komudy), dane jest doświadczyć czytelnikowi „tchnienia” tego, co wywodzi się z radykalnej „inności przeszłości” (określenie Franka R. Ankersmita; zob. Od postmodernistycznej narracji do po-postmodernistycznego doświadczenia. (Ewy Domańskiej rozmowa z Frankiem R. Ankersmitem), „Teksty Drugie” 1996, nr 2-3, s. 205). Można zresztą sygnalizowaną tu tendencję potraktować jako opozycyjną wobec powieści funkcjonujących w obiegu „wysokim”; w nim bowiem - co podkreśla Natalia Lemann - twórcy usiłują oddać specyficzny koloryt epoki, nie poprzestając na przejęciu ze źródeł jedynie sfery wydarzeniowej (zob. taż, Epicka historiografia we wspótczesnej prozie polskiej, Łódź 2008, s. 27).

${ }^{29}$ T. Parnicki, Wspótczesna polska powieść historyczna, [w:] tenże, Szkice literackie, Warszawa 1978, s. 116.

${ }^{30}$ Reprezentatywną dla tego problemu jest powieść Lewandowskiego Królowa Joanna D`Arc (2000), w której tytułowa bohaterka nie ginie na stosie w Ruoen, lecz zostaje ukryta na dworze Władysława III Warneńczyka. Poetyka historii alternatywnej - po którą sięga autor - usprawiedliwia takie "odstępstwo" od prawdy historycznej, zarazem uwaga zostaje przeniesiona $\mathrm{w}$ tym utworze na miłosno-wojenne perypetie bohaterów. Z takim instrumentalnym traktowaniem historii w twórczości artystycznej polemizuje Maciej Nowak; zob. tenże, Przeciw literackości na korzyść prawdy. Powieść historyczna i źródła, [w:] Zapisywanie historii. Literaturoznawstwo i historiografia, red. W. Bolecki, J. Madejski, Warszawa 2010, s. 172-186.

${ }^{31}$ E. Tierling-Śledź, Gra (z) historia. Powstanie styczniowe w prozie polskiej po 1945 roku, Szczecin 2013, s. 230.

32 Jedynie niekiedy, jak w wypadku twórczości Szczepana Twardocha, genologiczne „powinowactwa z wyboru” zostają sfunkcjonalizowane i podporządkowane spójnej wizji dziejów. O jednej z jego powieści Maciej Urbanowski pisze: „Gdyby [...] dokonać [...] syntezy 
jednakże - poprzez kontaminację wyznaczników genologicznych - zarazem nie tylko czytelniczy „horyzont oczekiwań", ale i przyjmowane przez odbiorców strategie lekturowe. Dzieje się tak, ponieważ potoczne doświadczenie odbiorców nakazuje identyfikację gatunkową utworu jako warunku koniecznego dla jego zrozumienia. Nieprzypadkowo Michał Głowiński zauważał korelację pomiędzy gatunkiem realizowanym przez dany utwór a jego interpretacją przez czytelnika ${ }^{33}$. Tymczasem, wówczas gdy w tekście zabraknie "czystości” gatunkowej, czytelnik zmuszony jest do poszukiwania - na podstawie uprzednich doświadczeń lekturowych - różnych kluczy interpretacyjnych, pozwalających mu na rozpoznanie konwencji wykorzystanych do kreacji świata przedstawionego ${ }^{34}$. Niekiedy zatem to sam czytelnik arbitralnie rozsądza czy ma do czynienia z utworem z kręgu popularnej powieści historycznej, czy też raczej należącym do kręgu literatury sensacyjnej/kryminalnej/romansowej utworem, którego akcja została osadzona w określonej czasowo epoce historycznej. Jeśli nawet bowiem odbiorca potraktuje przywoływane terminy genologiczne jako „znak-nazwę", pełniącą funkcję ochronną przed pomyłką interpretacyjną ( $\mathrm{w}$ takiej roli pojawiają się niekiedy podtytuły), nie musi podążać za sugestią autora ${ }^{35}$. Z pewnością kwestii tej nie rozwiązuje propozycja Jana Trzynadlowskiego, by traktować powieść historyczną jako gatunek wielopostaciowy ${ }^{36}$. Tym bardziej, że sprzeczności i wywołane nimi napięcia to strategie charakterystyczne dla literackiego kształtowania pamięci, której reprezentacją pozostaje gatunek $^{37}$. Co więcej, to właśnie owo ścieranie się przeciwstawnych tendencji można uznać za świadectwo żywotności gatunku. Ireneusz Opacki, na przykładzie ewolucji wariantów gatunkowych poezji podkreśla, że jedynie przemiany wzorców decydują o funkcjonowaniu gatunku ${ }^{38}$.

$\mathrm{Na}$ lekturowe konsekwencje takiej sytuacji komunikacyjnej zwraca uwagę Anna Gemra na marginesie rozważań nad "trylogią husycką" (2001-2006) Andrzeja Sapkowskiego. Według badaczki termin "fantasy

pisarstwa Twardocha, to wskazałbym na to, iż wyrastając $z$ fantastyki oryginalnie łączy ono jej konwencje z tradycjami powieści politycznej, psychologicznej, sensacyjnej a zwłaszcza historycznej” (tenże, „Wieczny Grunwald” Szczepana Twardocha, [w:] tenże, Romans z Polska. O literaturze wspótczesnej, Kraków 2014, s. 70).

${ }^{33}$ Zob. M. Głowiński, Gatunek literacki i problemy poetyki historycznej, [w:] Problemy teorii literatury, oprac. H. Markiewicz, Wrocław 1987, seria 2, s. 131.

${ }_{34}$ Do pewnego stopnia czytelnikowi pomagają obudowujące tekst właściwy parateksty (określenie Gerarda Génnetta; zob. tenże, Palimpsesty, przeł. A. Milecki, [w:] Wspótczesna teoria badań literackich za granica. Antologia, red. H. Markiewicz, Kraków 1992, t. 4, cz. 2, s. 320. $\mathrm{W}$ wypadku kryminału retro jest to dość często dołączone do utworu posłowie, odautorski komentarz, bądź deklaracje o takim charakterze udzielane w wywiadach. Legitymizują one osadzenie kryminalnej fabuły w scenerii historycznej.

${ }^{35}$ Zob. D. Pawelec, Paradoksy zamierania gatunku, [w:] Zamieranie gatunku, red. M. Ładoń, G. Olszański, Katowice 2015, s. 19.

${ }^{36}$ Zob. J. Trzynadlowski, Problemy genologiczne powieści historycznej, [w:] Problemy polskiej powieści historycznej po 1939 roku, red. J. Konieczny, Bydgoszcz 1987, s. 5.

${ }^{37}$ Zob. A. Erll, Literatura jako medium pamięci zbiorowej, s. 238.

${ }^{38}$ Zob. I. Opacki, Krzyżowanie się postaci gatunkowych jako wyznacznik ewolucji poezji, „Pamiętnik Literacki" 1963, z. 4, s. 382-383. Należy zdawać sobie oczywiście sprawę z różnicy w społecznym funkcjonowaniu poezji i literatury popularnej, wydaje się jednak, że Opacki wskazał na uogólniony do tego stopnia mechanizm umożliwiający "gatunkowe myślenie" o literaturze, że można odnieść go nie tylko do poezji. 
historyczna" wprowadza szczególne postrzeganie historii jako entureage'u niewykraczającego poza ramy atrakcyjnej fabularnie opowieści, a zarazem "wzbogaconego" o elementy charakterystyczne dla fantastyki baśniowej (magia, postacie nadprzyrodzone mające równy status ontologiczny z ludzkimi bohaterami $)^{39}$. Zarówno w przywołanym tu wypadku, jak i innych utworach z kręgu "fantasy historycznej" (między innymi w powieściach: Rafała Dębskiego, Kiedy Bóg umiera, 2007 oraz Roberta Forysia Za garść czerwońców, 2009), mamy do czynienia z opowieściami - w myśl rozpoznania Lidii Gąsowskiej - sytuującymi się pomiędzy nurtem elitarnym i rozrywkowym literatury $^{40}$. Ten pierwszy związany jest $\mathrm{z}$ postrzeganiem powieści historycznych jako "powieści o historii”, odwołujących się nierzadko do epickiej historiografii. Natalia Lemann - wypowiadając się ze stanowiska zbliżonego implicite do narratywistycznej koncepcji White'a (i pośrednio Barthesa) - określa je mianem „laboratoriów współczesnej historii" ${ }^{\prime 41}$. Z kolei nurt literatury - określany przez Gąsowską mianem "rozrywkowego" - dostarcza atrakcyjnego lekturowo schematu. W konsekwencji mam do czynienia z sytuacją, w której - posłużmy się sformułowaniem Lemann - „Każda powieść jest historyczna, nie każda natomiast jest o historii" ${ }^{\prime 42}$.

\section{Relacja pisarskich wizji historii z uzgodnionymi społecznie}

Naszkicowana wyżej przestrzeń sytuowania prozy historycznej ma charakter modelowy; nie uwzględnia też istotnego czynnika, jakim pozostaje jej funkcjonowanie $\mathrm{w}$ ramach paradygmatu postmodernistycznego ${ }^{43}$. Ten

${ }^{39}$ Zob. A. Gemra, Reinmara z Bielawy dolnośląskie i czeskie przypadki: "Trylogia husycka" Andrzeja Sapkowskiego, [w:] Śląskie pogranicza kultur, red. M. Ursel, O. Taranek-Wolańska, t. 1, Wrocław 2012, s. 209. Takie postrzeganie funkcji historii w "fantasy historycznej" nie jest równoznaczne z suponowaniem jej twórcom ignorancji na temat czasów, o których piszą. Znacząca pod tym względem pozostaje zresztą deklaracja Andrzeja Sapkowskiego, opowiadającego o przygotowaniach do pracy nad Narrenturm (2002): „Studiowałem dokumenty, aby móc potem pewnych wydarzeń uchwycić się fabularnie. Pokazać mojego bohatera na tle konkretnych wydarzeń dziejowych" (A. Sapkowski, S. Bereś, Historia i fantastyka, Warszawa 2005, s. 125).

${ }^{40}$ Zob. L. Gąsowska, Fantasy - gra z czytelnikiem o historię, "Śląskie Studia Polonistyczne” 2011, nr 1, s. 47.

${ }^{41}$ Zob. N. Lemann, Epicka historiografia we wspótczesnej prozie polskiej, s. 225. Jako punkt odniesienia dla stanowiska badaczki można przywołać koncepcję "historii fikcjonalnej” (histoire fiction) Pierre`a Nory; zob. tenże, Entre Mémoire et Histoire, [w:] Les lieux de mémoire, t. 1: La république, red. P. Nora, Paris 1984, s. XL.

${ }^{42}$ Tamże, s. 212. Reprezentatywne dla rozróżnienia Lemann pozostają uwagi Magdaleny Roszczynialskiej na temat historiozoficznego wymiaru "cyklu wiedźmińskiego" (19861999) Sapkowskiego; zob. taż, Popularna metapowieść historiozoficzna? Casus: cykl wiedźmiński Andrzeja Sapkowskiego, [w:] Powieść historyczna dawniej i dziś, s. 585-600.

${ }^{43} \mathrm{O}$ tym, do jakiego stopnia sygnalizowany tu problem funkcjonowania tekstu kultury w ramach paradygmatu postmodernistycznego może wpłynąć na postrzeganie i wartościowanie utworu literackiego, przekonuje nie tylko lektura "trylogii husyckiej” Sapkowskiego. Szczególnie wyraziście ów wpływ widać w fantastyce steampunkowej, traktowanej jako alternatywne opowieści o historii kontrfaktycznej (zob. N. Lemann, Steampunk [hasło do: Materiały do Słownika rodzajów literackich], "Zagadnienia Rodzajów Literackich” 2014, t. 57, z. 1, s. 344). Wówczas odpowiedź na zakładane implicite przez twórców historii alternatywnych (a do tego nurtu należy fantastyka steampunk) pytanie: "Jak być mogło?", zmienia się w historiozoficzny namysł nad mechanizmem dziejów i uwarunkowaniami wpływającymi na ich 
bowiem, co podkreśla Gianni Vattimo, funkcjonuje obierając jako punkt odniesienia dla swego istnienia przeszłość; „przypomina” ją i poddaje nieustannym redefinicjom ${ }^{44}$. Niebezpieczeństw, na jakie narażona jest $\mathrm{w}$ tym procesie pamięć o przeszłości, Tzvetan Todorov upatruje $\mathrm{w}$ „obsesji historycznej" ${ }^{\prime 45}$.

Niemała rola $\mathrm{w}$ tak określonej kulturze przypada aktualizacjom znaczeń, toteż nieprzypadkowo krytycy "trylogii husyckiej" Sapkowskiego akcentują współczesność jako punkt odniesienia dla artystycznej wizji wieków średnich. Przywołajmy (w porządku chronologicznym) dwa przykłady takich odczytań:

Z tytułowej Wieży Błaznów mamy widok na wiek XV pogrążony w chaosie, ale też na współczesnośćć;

Powieści husyckie, zaliczane do nurtu fantasy historycznej, są [...] tyleż powieściami o przeszłości, co dyskursem na temat współczesności, [...] zgodnie [...] z postmodernistyczną techniką mieszania dyskursów i sytuowania się pomiędzy historią i literaturą ${ }^{47}$.

Tym, co pozostaje wspólne dla przywołanych tu odczytań Narrenturm Sapkowskiego, jest przekonanie o niemożności lektury owej powieści poza kontekstem współczesności ${ }^{48}$. Zdaje się ono wynikać tyleż z przeświadczenia o funkcjonowaniu "trylogii husyckiej” w obrębie postmodernistycznej "kultury cytatu”, co o takim ukształtowaniu fabularnych zdarzeń, by

rozwój. Co więcej, alternatywny obraz dziejów może też być pretekstem do rozważań metahistorycznych, uwypuklających problematykę „mikro”, za której pośrednictwem badacz może mówić o zjawiskach w skali "makro". Nieprzypadkowo Ewa Domańska, kreśląc konsekwencje „zwrotu narratywistycznego” w historiografii, deklaruje: „Historia staje się opowieścią o świecie, który jest kontrwizerunkiem tego, w którym sami żyjemy" (taż, Filozoficzne rozdroża historii, s. 27). Tym samym historia alternatywna (a zatem i fantastyka steampunk) pozwala znaleźć punkt odniesienia dla rozważań o dziejach zaistniałych jako „awersie” dziejów niebyłych, lecz możliwych (zob. M. Parowski, Fantastyka alternatywna i jej wrogowie, „FRONDA LUX" 2014, nr 73, s. 156-165). Szczególnie wiele miejsca poświęca temu problemowi, sięgając po założenia logiki trójwartościowej i konfrontując ją z arystotelesowską, Jacek Dukaj w Lodzie (zob. N. Lemann, PODobni - NiePODobni. „Muza dalekich podróży” Teodora Parnickiego i "Lód" Jacka Dukaja jako przykład dwóch sposobów alternatywizacji historii, „Porównania” 2012, nr 10, s. 173-188; P. Gorliński-Kucik, Pamieć przeszłosci versus Historia. O "Lodzie" Jacka Dukaja, "Tematy i Konteksty" 2015, nr 5, s. 142-153).

${ }^{44}$ Zob. G. Vattimo, Ponowoczesność i kres historii, przeł. B. Stelmaszczyk, [w:] Postmodernizm. Antologia przekładów, red. R. Nycz, Kraków 1997, s. 137.

${ }_{45}$ Zob. T. Todorov, Les Abus de la Mémoire, Paris 2004, s. 51. Przejawem praktyk kulturowych, o których pisze badacz, mogą być grupy rekonstrukcyjne oraz ich udział w oficjalnych obchodach świąt państwowych.

${ }^{46}$ Z. Pietrasik, Widok z Wieży Błaznów, „Polityka” 2002 z dn. 26.10, nr 43, s. 68.

${ }^{47}$ N. Lemann, Epicka historiografia we wspótczesnej prozie polskiej, s. 141

${ }^{48}$ Osobną kwestią pozostaje, do jakiego stopnia można zaproponowane tu odczytania traktować jako aktualizację postulatów György Lukácsa, akcentującego konieczność spoglądania na historię z perspektywy współczesności (nawet wówczas, gdyby miało to prowadzić do uznania anachronizmu za warunek konieczny kreacji artystycznej). Zob. tenże, Klasyczna postać powieści historycznej, przeł. C. Przymusiński, [w:] tenże, Od Goethego do Balzaka. Studia z historii literatury XVIII i XIX wieku, Warszawa 1958, s. 316. 
stanowiły aluzję do pozatekstowej rzeczywistości ${ }^{49}$. Odwołania te mogą jednakże przybierać formułę nie tylko krytyki czytelniczej współczesności, ale $\mathrm{i}$ - jak w wypadku kryminału retro oraz fantastyki steampunk - autorskiego przekonania, że możliwe jest pisanie o przeszłości bez intencjonalnego dydaktyzmu ${ }^{50}$.

Znamienny dla obu wskazanych tu formuł popularnej powieści historycznej pozostaje krytyczny charakter przywołań minionych epok. Można oba nurty literatury popularnej odczytywać jako rozrachunek z przeszłością, lecz $\mathrm{w}$ istocie jest to rozliczenie $\mathrm{z}$ jej kulturowymi konstruktami. Znaczące, iż jedna $\mathrm{z}$ niewielu rodzimych powieści utrzymanych w poetyce fantastyki steampunk - Alkaloid (2012) Aleksandra Głowackiego - to pastisz-kontynuacja Lalki (1887-1889; wydanie osobne 1890) Bolesława Prusa ${ }^{51}$. Punktem odniesienia dla artystycznej kreacji staje się zatem w powieści Głowackiego nie historycznie weryfikowalna przeszłość, lecz jej literacka wizja. Nieprzypadkowo też Dariusz Piechota pośród inspiracji fantastyki steampunkowej upatruje zjawiska kulturowe charakterystyczne dla wieku XXI - estetykę MTV, filmy Quentina Tarantino oraz amerykański nurt „komiksu superbohaterskiego" 52 . Wyrażający się niekiedy w ostentacyjnych nawiązaniach intertekstualnych eskapizm fantastyki steampunk nie wyklucza oczywiście jej społecznego zaangażowania. Nieprzypadkowo Piechota wskazuje między innymi na możliwość ponownego odczytania kultury wiktoriańskiej przez pryzmat grup marginalizowanych w niej. W ten sposób utwory - w których pozornie dominuje funkcja ludyczna - dzięki spojrzeniu na nie z perspektywy krytyki postkolonialnej mogą ujawnić potencjał krytyczny ${ }^{53}$.

${ }^{49}$ Reprezentatywne dla naszkicowanej tu strategii Sapkowskiego zdają się rozważania o konsekwencjach przemian sztuki wojennej w związku z postępem technologicznym: „Wojna bez rycerstwa i rycerskości [...] musi wreszcie przerodzić się w zwykły mord. A w konsekwencji w ludobójstwo" (tenże, Narrenturm, Warszawa 2002, s. 76).

${ }^{50}$ Wobec "fantasy historycznej" kwestię tę podnosiła Natalia Lemann (zob. taż, Epicka historiografia we współczesnej prozie polskiej, s. 145).

${ }^{51}$ Inne rodzime powieści, określane przez „,krytykę wewnętrzną" mianem steampunkowych, nie spełniają kryterium osadzenia w epoce wiktoriańskiej (np. dylogia Krzysztofa Piskorskiego Zadra (2008-2009), której akcja rozgrywa się w czasie wojen napoleońskich) bądź też ich autorzy sięgają raczej po rekwizytornię przełomu XIX i XX wieku, łącząc ją z motywami właściwymi dla innych nurtów fantastyki. Charakterystyczne pod tym względem są: antologia Ostatni dzień pary (2013) oraz powieść Jana Maszczyszyna Światy solarne (2015). Do pewnego stopnia jako powieść sensu stricto steampunkową można odczytywać następujące utwory: Dukaja Lód (2007) oraz Lewandowskiego Orzeł bielszy niż gotębica (2013).

${ }_{52}$ Zob. D. Piechota, W otchtani Alki. Dalsze losy Wokulskiego w świetle steampunku, [w:] tenże, Między utopią a melancholią. W kręu nowoczesnej i ponowoczesnej literatury fantastycznej, Lublin 2015, s. 91.

${ }^{53}$ Zob. tamże, s. 89. Jest to jednakże właściwość charakterystyczna dla literatury steampunk obszaru anglojęzycznego, bo też i funkcjonuje ona w tym obszarze w szczególnej sytuacji komunikacyjnej jako instrument wzmacniania imperialnej przeszłości Wielkiej Brytanii (zob. N. Lemann, Polski steampunk, - zaadaptować historię, adaptując konwencję, „Biblioteka Postscriptum Polonistycznego" 2015, nr 5, s. 135). Co więcej, może odnosić się jedynie do literackiego aspektu funkcjonowania tego zjawiska w kulturze współczesnej. Jakkolwiek bowiem steampunk to obecnie również estetyka wpływająca m.in. na modę, jedynie twórcy literatury zdają sie dostrzegać potencjał krytyczny tej estetyki. Świadczy o tym uwaga jednego z uczestników dyskusji nad powieścią Krzysztofa Piskorskiego Czterdzieści i cztery (2016): „Steampunk w literaturze jest nie tylko źródłem gatunku, ale i nadzieją dla niego. Bo steampunk jako estetyka to stwór pożerający własny ogon - im więcej tych gogli i trybików, tym lepiej, 
Potencjał ten jednakże bywa wykorzystywany dość rzadko w rodzimych realizacjach powieści historycznej, sięgającej po możliwości oferowane przez różnorodnie motywowaną fantastykę. Owszem, ukazywane w poetyce steampunk dzieje powstania styczniowego w powieściach: Konrada T. Lewandowskiego Orzeł bielszy niż gołębica oraz Andrzeja Sawickiego Nadzieja czerwona jak śnieg (2011) mogą być traktowane jako krytyczny namysł nad polską mitologią narodową. Wydaje się jednak, że utwory te pozostają przede wszystkim świadectwem poszukiwań historycznego entourage' $u$ dla popularnych również nad Wisłą „opowieści o wieku pary”.

Tak jak steampunk sięga po rekwizytornię właściwą dla okresu wiktoriańskiego, dla kryminału retro najczęstszym punktem odniesienia jest kulturowy obraz dziejów Polski sprzed 1945 roku. Najczęściej (i chronologicznie najwcześniejszą) epoką przywoływaną przez twórców literatury sensacyjno-kryminalnej pozostaje międzywojnie. Świadczy o tym popularność utworów między innymi Marka Krajewskiego, Marcina Wrońskiego, Pawła Jaszczuka, z czasem tworzących osobne cykle literackie ${ }^{54}$. Fakt, iż opowieści te nie pozostają „osobne”, jest znaczący z perspektywy rynkowej (ta zaś powinna być rozpatrywana jako istotny kontekst funkcjonowania obiegu popkulturowego). Świadczy bowiem nie tylko o popularności poszczególnych twórców, którzy znaleźli w realiach wolnego rynku własne grono odbiorców, ale i czytelniczej akceptacji zaproponowanego im modelu widzenia przeszłości. Dość rychło jednak pojawiły się opowieści, których fabuła została osadzona w czasach przełomu XIX i XX wieku oraz - incydentalnie - wcześniej.

Niezależnie od różnic poetyki opowieści o przeszłości, wynikających z wyborów artystycznych pisarzy, łączy je przeświadczenie, że w popularnej powieści historycznej warstwa dziejowa ma charakter podrzędny wobec atrakcyjności fabuły; niebagatelną rolę $\mathrm{w}$ tym zakresie odgrywają też szczegóły obyczajowo-społeczne okresu, w którym osadzony zostaje utwór ${ }^{55}$. Z tego względu autorzy dążą do wyboru czasu akcji swych

a żeby to miało jakąś funkcję... Po co?" (Immo, [komentarz do szkicu Michała Cetnarowskiego Maszyneria wyzwolonej wyobraźni], „lubimyczytać.pl”, [online] http://lubimyczytac.pl/ aktualnosci/publicystyka/7696/maszyneria-wyzwolonej-wyobrazni, [wpis z dn. 25.09.2016; dostęp: 3.10.2016]).

${ }^{54}$ Utwory, których akcja zostaje osadzona w międzywojniu to m.in. powieści: Pawła Jaszczuka (Foresta Umbra, 2004; Plan Sary, 2011; Marionetki, 2012; Akuszer śmierci, 2013), Joanny Szwechłowicz (Tajemnica szkoty dla panien, 2014; Ostatnia wola, 2015), Ryszarda Ćwirleja (Tam ci będzie lepiej, 2015) oraz Małgorzaty Fugiel-Kuźmińskiej i Michała Kuźmińskiego (Sekret Kroke, 2009).

${ }^{55}$ Zob. B. Kaniewska, Doświadczenie historyczne w zapisie literackim, „Kultura Współczesna" 2007, nr 3, s. 122. Obecność szczegółu można zresztą interpretować w myśl propozycji Ewy Domańskiej, jako przejaw nieantropocentrycznego podejścia do badań nad wytworami kultury (przedmiotami codziennego użytku, rytuałami, modą). Badaczka podkreśla, że artefakty w perspektywie nowej humanistyki przestają być postrzegane jako produkt przeszłości, lecz interpretowane są jako „aktywni”, jakkolwiek pozbawieni intencjonalności "aktorzy", którzy pozostają zarazem integralnymi elementami stosunków międzyludzkich (zob. taż, Historie niekonwencjonalne. Refleksja o przeszłości w nowej humanistyce, Poznań 2006, s. 47). Z zaproponowanej tu perspektywy znacząca staje się tendencja do szczegółowego (nieomal dokumentarnego) opisu codzienności w kryminałach retro. Co więcej, owa „egzotyka dnia powszedniego" jest swoistym remedium na tezy głoszące „koniec historii” (zob. H. Gosk, Zamiast końca historii. Rozumienie oraz prezentacja procesu historycznego w polskiej prozie XX $i$ XXI wieku podejmującej tematy współczesne, Warszawa 2005, s. 228). 
opowieści, zajmującego stałe miejsce w pamięci kulturowej (takim jest zarówno wiek XVII, jak i międzywojnie; do pewnego stopnia również belle epoque). Za limes owej tendencji można uznać - dialektycznie - utwory proponujące "egzotykę sytuacyjną" poprzez umieszczenie bohatera w szczególnych sytuacjach, nie mieszczących się w „kanonie pamięci”. Należą do nich opowieści o powstaniu warszawskim. Formalnie reprezentują nurt kryminalno-detektywistyczny - jak Likwidator 44 (2014) Dominika Kozara, będący historią śledztwa w sprawie morderstwa popełnionego w pierwszych dniach powstania - bądź fantastyki grozy. Obiekt R/W0036 (2009) Tomasza Bukowskiego to opowieść o współpracy wydzielonego oddziału powstańczego z grupą naukowców nazistowskiego Forschungs - und Lehrgemeinschaft das Ahnenerbe e.V. w celu likwidacji bazyliszka [sic!], skrywającego się w warszawskich kanałach (jako kontrapunkt dla tych utworów można przywołać powieść Łukasza Orbitowskiego Widma, 2012). Z kolei akcja Czarnego mercedesa (2016) Janusza Majewskiego rozgrywa się w okupowanej Warszawie między innymi w getcie w restauracji "Sztuka”, w której występowała Wiera Gran i Miriam Ajzensztadt oraz Władysław Szpilman. Agnieszka Krawczyk natomiast w Nocy zimowego przesilenia (2014) ukazuje codzienność okupowanego Krakowa, zaś Krajewski w Festung Breslau (2006) obronę tytułowego miasta-twierdzy, w której trakcie Mock prowadzi śledztwo w sprawie morderstwa.

O tym, do jakiego stopnia autorzy dążą do oddania egzotyki obyczajowo-historycznej, świadczą dość liczne opisy potraw spożywanych przez bohaterów kryminału retro. Celuje w nich zwłaszcza Krajewski w cyklu powieści o Eberhardzie Mocku. Jako przykład przywołajmy scenę, w której protagonista spożywa kolację:

Mock wlał w siebie piekący strumień cytrynówki Krsinsika i zanurzył nóż w gruby sześcian masła przystrojony gałązkami pietruszki. Posmarował nim kromkę pszennego chleba, po czym wdarł się widelcem w delikatne wnętrze galaretki z nóżek. Prostopadłościenne i romboidalne bryły galarety, w których zastygły ósemki jajka, ząbki czosnku i pasma wieprzowiny, ginęły w ustach Mocka. [...] Na talerzu [...] wylądowały cztery zarumienione szyje gęsie. Pokroił ten specjał na plastry, a następnie poukładał je na chrupiących talarkach ziemniaków. W otoczce gęstej skóry zamknięty był farsz z cebuli, wątróbki i gęsiego smalcu. Mock nałożył na te piramidy miękkie pierścienie duszonej cebuli ${ }^{56}$.

Sensualizm opisu jedzenia spełnia podwójną funkcję - nie tylko bowiem „uwiarygodnia” (zwłaszcza w konfrontacji z poświadczoną historycznie ofertą zakładów gastronomicznych ${ }^{57}$ ) realizm szczegółu, ale i umożliwia pełniejszą immersję poprzez oddziaływanie wyobraźni na zmysł smaku.

${ }^{56}$ M. Krajewski, Widma w mieście Breslau, Warszawa 2005, s. 79-81.

${ }^{57} \mathrm{Na}$ ten temat zob. Czarne kryminaty z Breslau [fragmenty wywiadów], „Biuletyn Informacji Bibliotecznych i Kulturalnych Wojewódzkiej i Miejskiej Biblioteki Publicznej w Łodzi" 2010, nr 18, z dn. 12 października, s. 5. 
Jaką rolę pełni współcześnie popularna powieść historyczna? W myśl opinii Jakuba A. Malika jej zadanie polega głównie na opowiadaniu „ciekawej fabuły"58. Oczywiście społeczność, niezależnie od promowanych form „polityki pamięci" i ustaleń historyków, tworzy własną wizję przeszłości, nie troszcząc się zresztą zbytnio o jej „prawdziwość”. Naszkicowanej tu tendencji sprzyja moda na "historie prawdziwe”, pozostające literackim przejawem myślenia spiskowego; te zaś tworzą wprawdzie fałszywy z perspektywy badacza, jednak sugestywny obraz przeszłości, przemawiający do odbiorców $^{59}$. Dzieje się tak, ponieważ zdarzenia z porządku wiedzy historycznej wartościowane są w imaginarium communis - jak zauważa Ewa Nawrocka - wedle hierarchii potrzeb, toteż układane z nich sekwencje więcej mówią o teraźniejszości niż przeszłości ${ }^{60}$. Tendencję tę rozpoznaje Marek Zaleski jako stan domagający się upamiętnienia ${ }^{61}$.

Popularnej powieści historycznej przypadła w tym procesie „kulturowego zapamiętywania" rola (posłużmy się typologią Nawrockiej ${ }^{62}$ ) medium podtrzymującego i powtarzającego mity narodowe. Nawet jeśli bowiem, jak w wypadku twórczości Komudy i Krajewskiego, obraz minionych czasów zostaje rozbity, w miejsce dotychczasowego mitu powstaje nowy. Punktem odniesienia dla owego mitu w prozie przywołanych tu autorów pozostaje odpowiednio XVII wiek, przyswojony poprzez Sienkiewiczowską Trylogię, oraz międzywojnie, utożsamiane $\mathrm{z}$ obrazem wywiedzionym $\mathrm{z}$ nostalgicznych komedii filmowych (na przykład Hallo Szpicbródka, czyli ostatni występ Króla Kasiarzy, Polska 1978, reż. Janusz Rzeszewski, Mieczysław Jahoda) ${ }^{63}$.

Mit przeszłości, który można wysnuć z funkcjonujących w imaginarium communis tekstów kultury, ma niekiedy - wobec chronologicznie

${ }^{58}$ Zob. J. A. Malik, Przyczajony templariusz, ukryty Graal. Co zostało z powieści historycznej (we współczesnej powieści popularnej). Notatki do eseju, [w:] Powieść historyczna dawniej i dziś, s. 602.

${ }^{59}$ Trop, łączący myślenie spiskowe $\mathrm{z}$ historią kontrfaktyczną oraz relację pomiędzy literaturą a historią spiskową, podaję w ślad za wystąpieniem dr hab. prof. UZ Bogdana Trochy (Uniwersytet Zielonogórski) Autorstwo jako zagadka detektywistyczna: "Kod Szekspira” Virginii Fellows, przedstawionym na konferencji naukowej Szekspirowskie tropy w kryminale, zorganizowanej przez Pracownię Badań nad Kulturą Popularną i Nowymi Mediami Uniwersytetu Wrocławskiego, towarzyszącej Międzynarodowemu Festiwalowi Kryminału we Wrocławiu w dn. 29.05-3.06.2016 (praca w druku).

${ }^{60}$ Zob. E. Nawrocka, Powieść jako apokryf historii. Pisarstwo historyczne Władysława Terleckiego, [w:] Zapisywanie historii..., s. 247.

${ }^{61}$ Zob. M. Zaleski, Świat powtórzony, [w:] tenże, Formy pamięci, Gdańsk 2004, s. 26.

${ }^{62}$ Zob. E. Nawrocka, Powieść jako apokryf historii. Pisarstwo historyczne Władysława Terleckiego, s. 26. Nawrocka pisze intencjonalnie o strategiach, jakie może przyjąć pisarz historyczny (w tym wypadku Terlecki), jednakże jej konstatacje zdają się uogólnione i wskazują na społeczno-kulturowe uwikłanie artystycznej wizji przeszłości utrwalonej w dziele literackim.

${ }^{63} \mathrm{O}$ tym, iż mamy do czynienia ze zjawiskiem kulturowym szerszym niż twórczość pojedynczych autorów, świadczy to, że obie epoki zostają przywoływane również przez innych pisarzy. Lewandowski, oprócz cyklu kryminałów retro osadzonych w okresie międzywojennym, jest również autorem opowieści osnutych na tle XVII-wiecznych dziejów Polski, tworzących cykl Diabłu ogarek (Czarna wierzba, 2011; Kolumna Zygmunta, 2012; Ostatni hołd, 2013). Powieści te nie tylko dyskontują stworzoną przez Komudę modę na wiek XVII, ale i proponują alternatywną wizję poetyki opisu tego okresu (miejsce realizmu szczegółów historycznych zajmują awanturnicze perypetie bohaterów). 
wcześniejszego - charakter „anty-mitu”. Wartości zostają w nim zrelatywizowane bądź obraz epoki ulega takim przekształceniom, aby możliwe stało się ukazanie „kulturowego rewersu” dotychczasowej wizji ${ }^{64}$. Jednakże jego funkcja pozostaje niezmienna - ma utrwalać dotychczasowe postrzeganie przeszłości, choćby expressis verbis deklarowana była konieczność rewindykacji. Znamienne pod tym względem pozostają zabiegi marketingowe, kreujące Komudę na "anty-Sienkiewicza”; jako ich przykład służy recenzja jednego z tomów opowiadań tego autora: „W przeciwieństwie do Sienkiewicza Komuda wikła swoich bohaterów w sieć wydarzeń niemających nic wspólnego z doniosłością i walką o słuszną sprawę"65.

„Czytanie historii", utożsamiane w myśl propozycji rozumienia tej formuły przez Bogumiłę Kaniewską ${ }^{66} \mathrm{z}$ literacką interpretacją minionych czasów, pozostaje w popularnej powieści historycznej nadal zapisem o charakterze „kulturowego palimpsestu” z różnymi warstwami przeszłości nakładającymi się na siebie ${ }^{67}$. Tym samym proponowane czytelnikowi obrazy epok przywoływanych przez twórców są dalekie od poświadczonych historycznie. Odwołują się oni bowiem nie do historii, lecz funkcjonujących w wyobraźni społecznej „fantomów” przeszłości ${ }^{68}$. Czynią jednak to w sposób właściwy obiegowi popularnemu, którego zadaniem ma być kompensacja przeżyć czytelniczych, toteż nawet obrazy zapowiadane jako rewidujące dotychczasowe wizje pozostają takimi jedynie w stopniu nie większym, niż oczekuje tego odbiorca $^{69}$.

${ }^{64}$ Znaczące pod tym względem pozostają - utrzymane w naturalistycznej poetyce - opisy aktów kanibalizmu pośród polskiej załogi okupującej Kreml (1610-1612) w jednym z opowiadań Komudy Veto (1995) oraz epizod z powieści Bukowskiego Obiekt R/W0036, ukazujący okrucieństwo powstańca: „Dopiero przed wieczorem Niemcy znaleźli swoich snajperów. [...] Na środku pokoju siedzieli naprzeciw siebie przywiązani do krzeseł obaj strzelcy. Mieli wyłupione oczy. Ktoś obciął im także uszy i nosy. Duże fragmenty skóry zostały zdarte z twarzy, a brzuchy były rozprute [...]. Ofiary nadal jeszcze żyły i wyły niemiłosiernie" (T. Bukowski, Obiekt R/W0036, Warszawa 2009, s. 104-105).

${ }^{65}$ A. Dąbrowska, Na zielonej Ukrainie [rec. J. Komuda, Wilcze gniazdo], „Nowa Fantastyka” 2003, nr 10, s. 72. Z kolei w notce biograficznej dołączonej do powieści Komudy Bohun czytamy: „Pisarz sam mówi o sobie, że zaczął pisać literaturę historyczną, bo miał już dość popłuczyn po Sienkiewiczu [...]. Zdecydował się odtworzyć wspaniały świat szlachty polskiej, nie popadając przy tym w przesadę i bohaterszczyznę (J. Komuda, Bohun, Lublin 2006, skrzydełko przedniej okładki).

${ }^{66}$ Zob. B. Kaniewska, Wielka historia w małym świecie. Doświadczenie historyczne w twórczości Wiestawa Myśliwskiego, [w:] Zapisywanie historii..., s. 249.

${ }^{67}$ Zob. R. Traba, Społeczne ramy czytania historii, [w:] Przemiany pamięci społecznej a teoria kultury, red. B. Korzeniewski, Poznań 2007, s. 57.

${ }^{68} \mathrm{Te}$ z kolei wypierają ze świadomości zbiorowej obrazy „prawdziwej” historii, co podważa realizm owych powieści (Anna Gemra określa go mianem „realizmu pozorowanego"; zob. taż, Eberhard Mock na tropie: Breslau/Wrocław w powieściach Marka Krajewskiego, [w:] Śląskie pogranicza kultur, red. M. Ursel, O. Taranek-Wolańska, t. 2, Wrocław 2013, s. 135). Proces ten można uznać zresztą za przejaw negocjowania znaczeń między historią i pamięcią stymulowaną tekstami kultury.

${ }^{69}$ Przeciwnie w obiegu wysokoartystycznym - tu zarówno tematyka powieści historycznej (np. Holocaust, trauma wojny i okupacji), jak i poetyka skłaniają do postawienia tezy o poszukiwaniu środków wyrazu w obliczu niewystarczalności dotychczasowych form ekspresji. Przykładem twórczość m.in. Romy Ligockiej (Dziewczynka w czerwonym płaszczyku, 2001), Michała Głowińskiego (Czarne sezony, 2002), Agaty Tuszyńskiej (Rodzinna historia lęku, 2005) bądź Magdaleny Tulli (Włoskie szpilki, 2011). Przy wszystkich różnicach spowodowanych immanentną poetyką przywołanych pisarzy, łączy ich przeświadczenie o konieczności 


\section{B I B LIO GRA F I A}

Abramowska J., Topos i niektóre miejsca wspólne badań literackich, „Pamiętnik Literacki" 1982, z. 1-2, s. 3-23.

Ankersmit F. R., Od postmodernistycznej narracji do po-postmodernistycznego doświadczenia. (Ewy Domańskiej rozmowa z Frankiem R. Ankersmitem), „Teksty Drugie" 1996, nr 2-3, s. 190-209.

Appleby J., Hunt L., Jacob M., Powiedzieć prawdę o historii, przeł. S. Amsterdamski, Poznań 2000.

Arystoteles, Topiki. O dowodach sofistycznych, przeł. K. Leśniak, Warszawa 1978.

Assmann J., Pamięć kulturowa. Pismo, zapamiętywanie i polityczna tożsamość w cywilizacjach starożytnych, przeł. A. Kryczyńska-Pham, Warszawa 2008.

Barthes R., Dyskurs historii, przeł. A. Rysiewicz, Z. Kloch, „Pamiętnik Literacki" 1984 , z. 3, s. 225-236.

Bartoszyński K., Konwencje gatunkowe powieści historycznej, „Pamiętnik Literacki" 1984 , z. 2, s. 3-44.

Bukowski T., Obiekt R/W0036, Warszawa 2009.

Czapliński P., Świat podrobiony. Krytyka i literatura wobec nowej rzeczywistości, Kraków 2003.

Ćwirlej R., Tam ci będzie lepiej, Poznań 2015.

Dąbrowska A., Na zielonej Ukrainie [rec. J. Komuda, Wilcze gniazdo], „Nowa Fantastyka" 2003, nr 10, s. 72.

Domańska E., Filozoficzne rozdroża historii, [w:] E. Domańska, J. Topolski, W. Wrzosek, Między modernizmem a postmodernizmem. Historiografia wobec zmian w filozofii dziejów, Poznań 1994, s. 17-30.

Domańska E., Historie niekonwencjonalne. Refleksja o przeszłości w nowej humanistyce, Poznań 2006.

Dukaj J., Lód, Kraków 2007.

Erll A., Literatura jako medium pamięci zbiorowej, przeł. M. Saryusz-Wolska, [w:] Pamięć zbiorowa i kulturowa. Wspótczesna perspektywa niemiecka, red. M. Saryusz-Wolska, Kraków 2009, s. 211-248.

Fugiel-Kuźmińska M., Kuźmiński M., Sekret Kroke, Warszawa 2009.

Gąsowska L., Fantasy - gra z czytelnikiem o historię, „Śląskie Studia Polonistyczne" 2011, nr 1, s. 45-52.

Gemra A., Eberhard Mock na tropie: Breslau/Wrocław w powieściach Marka Krajewskiego, [w:] Ślaskie pogranicza kultur, red. M. Ursel, O. Taranek-Wolańska, t. 2, Wrocław 2013, s. 119-143.

poszukiwań „,osobnego języka”, zdolnego do wyrażenia doświadczenia traumy (zob. A. Szczepan, Polski dyskurs posttraumatyczny. Literatura polska ostatnich lat wobec Holokaustu i tożsamości żydowskiej, [w:] Kultura po przejściach, osoby z przeszłościa. Polski dyskurs postzależnościowy - konteksty i perspektywy badawcze, red. R. Nycz, Kraków 2011, s. 239-256; N. Żórawska, Homo holocaustus, czyli holocaustowe doświadczenia autobiograficzne kobiet, "Tematy i Konteksty” 2015, nr 5, s. 126-141). 
Gemra A., Reinmara z Bielawy dolnoślaskie i czeskie przypadki: „Trylogia husycka” Andrzeja Sapkowskiego, [w:] Ślaskie pogranicza kultur, red. M. Ursel, O. Taranek-Wolańska, Wrocław 2012, t. 1, s. 205-221.

Génnette G., Palimpsesty, przeł. A. Milecki, [w:] Współczesna teoria badań literackich za granica. Antologia, red. H. Markiewicz, Kraków 1992, t. 4, cz. 2, s. 316-366.

Gluza Z., Powinności polityki historycznej, [online] http://historiaimedia.org/ wp-content/uploads/2008/09/powinnosci_polityki_historycznej.pdf (dostęp: 10.09.2016).

Głowiński M., Czarne sezony, Kraków 2002.

Głowiński M., Gatunek literacki i problemy poetyki historycznej, [w:] Problemy teorii literatury, oprac. H. Markiewicz, Wrocław 1987, seria 2, s. 109-129.

Gorliński-Kucik P., Pamięć przeszłości versus Historia. O „Lodzie” Jacka Dukaja, „Tematy i Konteksty” 2015, nr 5, s. 142-153.

Gosk H., Zamiast końca historii. Rozumienie oraz prezentacja procesu historycznego w polskiej prozie XX i XXI wieku podejmującej tematy współczesne, Warszawa 2005.

Hirsch M., The Generation of Postmemory, „Poetic Today” 2008, nr 1, s. 103-128.

Hutcheon L., Historiograficzna metapowiesć: parodia i Intertekstualność historii, przeł. J. Margański, [w:] Postmodernizm. Antologia przekładów, red. R. Nycz, Kraków 1998, s. 378-398.

Immo, [komentarz do szkicu Michała Cetnarowskiego Maszyneria wyzwolonej wyobraźni], „lubimyczytać.pl”, [online] http://lubimyczytac.pl/aktualnosci/publicystyka/7696/maszyneria-wyzwolonej-wyobrazni, (wpis z dn. 25.09.2016; dostęp: 3.10.2016).

Janicki K., Epoka hipokryzji. Seks i erotyka w przedwojennej Polsce, Kraków 2015. Janion M., Kres paradygmatu, „Rzeczpospolita” 1992, nr 63, s. 8-9.

Jarowiecki J., O powieści historycznej Józefa Ignacego Kraszewskiego, Kraków 1991. Jasłowski Z., Koń a sprawa polska: dwór, pałac i stadnina, „RODAKpress. Magazyn Politycznie Niepoprawny", [online] http://www.rodaknet.com/ rp_jaslowski_8.htm (dostęp: 15.09.2016).

Jaszczuk P., Akuszer śmierci, Warszawa 2013.

Jaszczuk P., Foresta Umbra, Poznań 2004.

Jaszczuk P., Marionetki, Poznań 2012.

Jaszczuk P., Plan Sary, Warszawa 2011.

Kaniewska B., Doświadczenie historyczne w zapisie literackim, „Kultura Wspó1czesna" 2007, nr 3, s. 119-128.

Kaniewska B., Wielka historia w małym świecie. Doświadczenie historyczne w twórczości Wiesława Myśliwskiego, [w:] Zapisywanie historii. Literaturoznawstwo i historiografia, red. W. Bolecki, J. Madejski, Warszawa 2010, s. $248-260$.

Kaniowska K., »Memoria« $i$ »postpamiecć« a antropologiczne badanie wspólnoty, „Łódzkie Studia Etnograficzne”: Codzienne i niecodzienne. O wspólnotowości w realiach dzisiejszej Łodzi, Łódź 2004, t. 43.

Klein K. L., O pojawieniu się pamięci w dyskursie historycznym, przeł. M. Bańkowski, „Konteksty” 2003, nr 3-4, s. 42-56.

Komuda J., Bohun, Lublin 2006.

Komuda J., Hubal, Lublin 2016. 
Komuda J., Warchoty i pijanice, czyli poczet hultajów z czasów Rzeczypospolitej szlacheckiej, Lublin 2004.

Krajewski M., Widma w mieście Breslau, Warszawa 2005.

Legeżyńska A., Literatura polska po 1989 roku wobec uniwersum tradycji, [w:] Transformacja w kulturze i literaturze polskiej 1989-2004, red. B. Bakuła, Poznań 2007, s. 11-51.

Lemann N., Epicka historiografia we wspótczesnej prozie polskiej, Łódź 2008.

Lemann N., PODobni - NiePODobni. „Muza dalekich podróży” Teodora Parnickiego i "Lód” Jacka Dukaja jako przykład dwóch sposobów alternatywizacji historii, „Porównania” 2012, nr 10, s. 173-188.

Lemann N., Polski steampunk - zaadaptować historię, adaptując konwencje, „Biblioteka Postscriptum Polonistycznego" 2015, nr 5, s. 133-147.

Lemann N., Steampunk [hasło do: Materiały do "Słownika rodzajów literackich”], "Zagadnienia Rodzajów Literackich" 2014, nr 57, z. 1, s. 344-349.

Lewandowski K. T., Bogini z Labradoru, Wrocław 2007.

Lewandowski K. T., Czarna wierzba, Warszawa 2011.

Lewandowski K. T., Elektryczne perty, Wrocław 2008.

Lewandowski K. T., Kolumna Zygmunta, Warszawa 2012.

Lewandowski K. T., Królowa Joanna D`Arc, Warszawa 2000.

Lewandowski K. T., Magnetyzer, Wrocław 2007.

Lewandowski K. T., Orzeł bielszy niż gotębica, Warszawa 2013.

Lewandowski K. T., Ostatni hołd, Warszawa 2013.

Lewandowski K. T., Perkalowy dybuk, Wrocław 2009.

Lewandowski K. T., Rumuńskie kawony, Warszawa 2015.

Lewandowski K. T., Śląskie dziękczynienie, Wrocław 2010.

Ligocka R., Dziewczynka w czerwonym płaszczyku, Kraków 2001.

Lukács G., Klasyczna postać powieści historycznej, przeł. C. Przymusiński, [w:] tenże, Od Goethego do Balzaka. Studia z historii literatury XVIII $i$ XIX wieku, Warszawa 1958, s. 237-318.

Lyszczyna J., Romantycy - nasi wspótcześni?, „Postscriptum” 2002, nr 4, s. 6-14.

Łoboz M., My, Europejczycy... Romantyków krajowych przekraczanie bliższych $i$ dalszych granic, [w:] Romantyzm krajowy - profil lokalny i oswajanie Europy, red. M. Łoboz, A. Kuniczuk-Trzcinowska, Wrocław 2016, s. 7-13.

Mach A., Świadkowie świadectw. Postpamięć Zagłady w polskiej literaturze najnowszej, Warszawa-Torun 2016.

Malik J. A., Przyczajony templariusz, ukryty Graal. Co zostato z powieści historycznej (we wspótczesnej powieści popularnej). Notatki do eseju, [w:] Powieść historyczna dawniej i dziś, red. R. Stachura, T. Budrewicz, B. Faron, K. Gajda, Kraków 2007, s. 601-609.

Małochleb P., Przepisywanie historii. Powstanie styczniowe w powieści polskiej w perspektywie pamięci kulturowej, Warszawa-Torun 2014.

Martuszewska A., Czym „ta trzecia” kusi badacza literatury?, [w:] taż, „Ta trzecia". Problemy literatury popularnej, Gdańsk 1997, s. 7-25.

Maszczyszyn J., Światy solarne, Stawiguda 2015.

Napiórkowski M., Powstanie umartych. Historia pamięci 1944-2014, Warszawa 2016. 
Nawrocka E., Powieść jako apokryf historii. Pisarstwo historyczne Władystawa Terleckiego, [w:] Zapisywanie historii. Literaturoznawstwo i historiografia, red. W. Bolecki, J. Madejski, Warszawa 2010, s. 234-247.

Nora P., Entre Mémoire et Histoire, [w:] Les lieux de mémoire, t. 1: La république, red. P. Nora, Paris 1984, s. XVII-XLII.

Nowak M., Przeciw literackości na korzyść prawdy. Powieść historyczna i źródła, [w:] Zapisywanie historii. Literaturoznawstwo i historiografia, red. W. Bolecki, J. Madejski, Warszawa 2010, s. 172-186.

Opacki I., Krzyżowanie się postaci gatunkowych jako wyznacznik ewolucji poezji, „Pamiętnik Literacki” 1963, z. 4, s. 349-389.

Pakier M., Pogranicza pamięci i postpamięci. O Zagładzie i kulturze masowej raz jeszcze, [w:] Peryferie i pogranicza: o potrzebie różnorodności, red. B. Jałowiecki, S. Kapralski, Warszawa 2011, s. 265-282.

Parnicki T., Wspótczesna polska powieść historyczna, [w:] tenże, Szkice literackie, Warszawa 1978, s. 103-114.

Parowski M., Fantastyka alternatywna i jej wrogowie, „FRONDA LUX” 2014, nr 73, s. 156-165.

Pawelec D., Paradoksy zamierania gatunku, [w:] Zamieranie gatunku, red. M. Ładoń, G. Olszański, Katowice 2015, s. 11-22.

Piechota D., Wotchtani Alki. Dalsze losy Wokulskiego w świetle steampunku, [w:] tenże, Między utopia a melancholia. W kregu nowoczesnej i ponowoczesnej literatury fantastycznej, Lublin 2015, s. 85-102.

Pietrasik Z., Widok z Wieży Błaznów, „Polityka” 2002 z dn. 26.10, nr 43, s. 68.

Pisać historię z która można żyć. Z Haydenem Whitem rozmawia Stawomir Sierakowski, „Krytyka Polityczna” 2005, nr 7-8, s. 227-230.

Piskorski K., Zadra, Warszawa 2008-2009.

Roszczynialska M., Popularna metapowieść historiozoficzna? Casus: cykl wiedźmiński Andrzeja Sapkowskiego, [w:] Powieść historyczna dawniej i dziś, red.

R. Stachura, T. Budrewicz, B. Faron, K. Gajda, Kraków 2007, s. 585-600.

Sapkowski A., Bereś S., Historia i fantastyka, Warszawa 2005.

Sapkowski A., Narrenturm, Warszawa 2002.

Sikora A., Dzieje Polski w obrazach fabularnych Józefa Ignacego Kraszewskiego jako przykład beletrystyki popularnej, [w:] Powieść historyczna dawniej i dziś, red. R. Stachura, T. Budrewicz, B. Faron, K. Gajda, Kraków 2007, s. 162-174.

Stownik literatury popularnej, red. T. Żabski, Wrocław 2006 [wydanie II, poprawione i uzupełnione], hasło: Powieść historyczna, s. 459-464.

Stanios-Korycka E., Między pamięcia kulturowa a kultura popularną. Wybrane aspekty relacji na przykładzie sposobów kreowania Bizancjum w historiach alternatywnych, „Acta Humana” 2014, nr 1, s. 51-66.

Szczepan A., Polski dyskurs posttraumatyczny. Literatura polska ostatnich lat wobec Holokaustu i tożsamości żydowskiej, [w:] Kultura po przejściach, osoby z przeszłością. Polski dyskurs postzależnościowy - konteksty i perspektywy badawcze, red. R. Nycz, Kraków 2011, s. 239-256.

Szwechłowicz J., Ostatnia wola, Warszawa 2015.

Szwechłowicz J., Tajemnica szkoły dla panien, Warszawa 2014.

Tazbir J., Powieść historyczna odbiciem wspótczesności, [w:] tenże, Prace wybrane, red. S. Grzybowski, t. 5: Szkice o literaturze i sztuce, Kraków 2002, s. 301-331. 
Terlecki O., Dwie głowy ptaka, [w:] tenże, Dwie głowy ptaka. Powrót z Carskiego Sioła, Warszawa 1975.

Tierling-Śledź E., Gra (z) historią. Powstanie styczniowe w prozie polskiej po 1945 roku, Szczecin 2013.

Todorov T., Les Abus de la Mémoire, Paris 2004.

Topolski J., Jak się pisze i rozumie historię. Tajemnice narracji historycznych, Warszawa 1996.

Traba R., Społeczne ramy czytania historii, [w:] Przemiany pamięci społecznej a teoria kultury, red. B. Korzeniewski, Poznań 2007, s. 43-64.

Trzynadlowski J., Problemy genologiczne powieści historycznej, [w:] Problemy polskiej powieści historycznej po 1939 roku, red. J. Konieczny, Bydgoszcz 1987, s. 5-27.

Tulli M., Włoskie szpilki, Warszawa 2011.

Tuszyńska A., Rodzinna historia lęku, Kraków 2005.

Urbanowski M., "Wieczny Grunwald” Szczepana Twardocha, [w:] tenże, Romans $z$ Polska. O literaturze współczesnej, Kraków 2014, s. 70-75.

Vattimo G., Ponowoczesność i kres historii, przeł. B. Stelmaszczyk, [w:] Postmodernizm. Antologia przekładów, red. R. Nycz, Kraków 1997, s. 128-144.

Wallis M., Wartości estetyczne łagodne i ostre, [w:] tenże, Przeżycie i wartość. Pisma z estetyki i nauki o sztuce 1931-1949, Kraków 1968, s. 185-209.

Weinberg J., Aleksander Bronikowski a historia - na przykładzie jednej powieści, "Annales Universitatis Mariae Curie-Skłodowska. Sectio FF" 2002-2003, t. XX-XXI, s. 289-299.

White H., Metahistory: The Historical Imagnation in Nineteenth-Century Europe, Baltimore-London 1975.

Zaleski M., Naprzód w przeszłość, [w:] tenże, Formy pamięci, Gdańsk 2004, s. 176-190.

Zaleski M., Świat powtórzony, [w:] tenże, Formy pamięci, Gdańsk 2004, s. 11-60.

Zieliński B., Serbska powieść historyczna, Poznań 1998.

Żórawska N., Homo holocaustus, czyli holocaustowe doświadczenia autobiograficzne kobiet, "Tematy i Konteksty” 2015, nr 5, s. 126-141.

\section{STRESZCZENIE}

Popularnej powieści historycznej przypadła współcześnie - niezależnie od promowanych form "polityki pamięci" i ustaleń historyków - rola medium podtrzymującego i powtarzającego mity narodowe. Nawet jeśli bowiem obraz minionych czasów zostaje rozbity, w miejsce dotychczasowego mitu powstaje nowy. Ma on niekiedy - wobec chronologicznie wcześniejszego - charakter „anty-mitu”, tj. ukazuje „kulturowy rewers" dotychczasowej wizji. Jednakże jego funkcja pozostaje niezmienna - ma utrwalać dotychczasowe postrzeganie przeszłości, choćby expressis verbis deklarowana była konieczność rewindykacji. „Czytanie historii” przez twórców popularnej powieści historycznej pozostaje w niej zapisem o charakterze „kulturowego palimpsestu", podporządkowanego funkcjonującym w wyobraźni społecznej „fantomom” przeszłości. 


\section{Słowa kluczowe}

literatura polska, literatura popularna, powieść historyczna, pamięć

\section{S U M M A R Y}

\section{Modern Polish historical novel and popular culture (prolegomenom)}

Regardless of the promoted 'politics of memory' and the results of historical research, the popular historical novel these days has been attributed the role of a medium that maintains and perpetuate national myths. Even if any given image of the past times is shattered, it is always substituted by a new myth, which in its nature is an 'anti-myth', when compared to the previous one, i.e. it presents a 'spiritual reverse' of the former vision. The function of the new myth, however, remains unchanged - it's meant to consolidate the to-date perception of the past, even despite an explicit demand for the necessity of revindication. 'Reading history' by authors of popular historical novels still remains a record which, in its nature, resembles a 'cultural palimpsest' and is subordinated to 'phantoms' dwelling in the social imagination.

\section{Keywords}

Polish literature, popular literature, historical novel, memory 